(C) 2014. This manuscript version is made available under the CC-BY-NC-ND 4.0 license http:// creativecommons.org/licenses/by-nc-nd/4.0/

\title{
DUAL EMBEDDEDNESS, INFLUENCE AND PERFORMANCE OF INNOVATING SUBSIDIARIES IN THE MULTINATIONAL CORPORATION
}

\author{
Francesco Ciabuschi \\ Department of Business Studies \\ Uppsala University \\ Ulf Holm* \\ Department of Business Studies \\ Uppsala University \\ Box 513, SE-751 20 Uppsala, SWEDEN \\ Phone: +46-18-471 1612 \\ Fax: +46-18-4716810 \\ E-mail: ulf.holm@fek.uu.se
}

Oscar Martín Martín

Public University of Navarre/ Uppsala University

Business Administration Department/ Department of Business Studies

Campus Arrosadía s/n, 31006 Pamplona, Navarre (Spain)

$$
\begin{gathered}
\text { Tel.: +34948166082 } \\
\text { Fax: +34948169404 } \\
\text { E-mail: oscar.martin@ unavarra.es }
\end{gathered}
$$

*Corresponding author 


\title{
DUAL EMBEDDEDNESS, INFLUENCE AND PERFORMANCE OF INNOVATING \\ SUBSIDIARIES IN THE MULTINATIONAL CORPORATION
}

\begin{abstract}
This study adopts a business network view to study the effects of subsidiary embeddedness on both subsidiary influence within the MNC and innovation-related business performance. Through Structural Equation Modeling we analyze subsidiary relationships connected to 85 innovation projects. The results show that external and corporate embeddedness are complementary contexts, although they affect subsidiary influence and performance differently. Whereas external embeddedness directly affects innovation-related business performance, corporate embeddedness strengthens the subsidiary's influence within the MNC, which in turn positively relates to performance. Moreover, as the study also finds that external and corporate embeddedness are positively associated, it stresses the issue of simultaneously balancing both external and corporate relationships (i.e. dual embeddedness) to nurture innovation projects.
\end{abstract}

Keywords: Dual embeddedness; Business networks; Corporate embeddedness; External embeddedness; Innovation development; Innovation performance; Subsidiary influence. 


\section{INTRODUCTION}

It is frequently argued that the ability to innovate is a source of competitive advantage, particularly in multinational corporations (MNCs), where innovation often occurs at the subsidiary level (Birkinshaw \& Hood, 1998; Pearce, 1999; Schmid \& Schurig, 2003). Subsidiary innovation has been associated with a variety of driving factors, such as autonomy (Cantwell \& Mudambi, 2005; Ghoshal \& Bartlett, 1988), geographic factors or distance from headquarters (Frost, 2001; Porter \& Sölvell, 1998; Prahalad \& Doz, 1981), communication (e.g., Schultz, 2003), dynamics in the business environment (Porter, 1990), and embeddedness in network relationships (Andersson, Forsgren, \& Holm, 2002; Hallin, Holm, \& Sharma, 2011). Our study is related to the latter stream of research and explores how the embeddedness of subsidiaries, during innovation development, affects the performance of innovations.

The direct relation between embeddedness and performance is extensively discussed in the literature on innovation, which essentially suggests that the strength of relationships provides a capability for learning that enhances the ability to evaluate innovation requirements among business actors (Cho \& Pucik, 2005; Dyer \& Singh, 1998; Echols \& Tsai, 2005; Moran, 2005; Uzzi, 1996). Departing from the argument that subsidiaries often retain corporate as well as external relationships (Almeida \& Phene, 2004; Bouquet \& Birkinshaw, 2008; Forsgren, Holm, \& Johanson, 2005), we move forward by investigating the relation between the corporate and external embeddedness of those relationships and their concurrent effects on innovation-related business performance. We thereby explore the effects of embeddedness in a "dual" business context of subsidiaries, which is an increasingly addressed distinction in the MNC literature. For instance, Achcaoucaou, Miravitlles and León-Darder (2013), recently proposed an analytical framework centred on dual embeddedness for the analysis of subsidiary competence-creation mandates. However, as Meyer, Mudambi and Narula (2011) noted, there has been hardly any empirical research into the simultaneous impact of corporate and external embeddedness. In fact, most research has either analyzed the impact of the external network or the corporate network, and it is, therefore, unclear how innovations within the respective contexts relate to the business performance of subsidiaries. Although there seems to be a belief that embeddedness is positively associated with innovation performance, corporate and external relationships may pull subsidiary innovations in different directions, creating a 'trade-off' between the 
two contexts whereby the subsidiary must balance its corporate embeddedness with its local external embeddedness (ibid.).

In this study, we also propose that subsidiary influence within the MNC is a mediating mechanism in the embeddedness-performance relationship. One side of this mechanism concerns the fact that surprisingly few studies have dealt with the association between embeddedness and the ability of subsidiaries to influence decisions on the internal resource distribution. Hence, embeddedness for innovation can be viewed as a critical resource controlled by the subsidiary, which provides a favorable position from which the subsidiary can exercise its influence on corporate decisions (Andersson, Forsgren \& Holm, 2007; Bouquet \& Birkinshaw, 2008; Ghoshal \& Bartlett, 1990; Medcof, 2001). In fact, the need to generate corporate resources may be essential as various types of costs occur when innovations are incorporated in business activities. Then again, these resources and costs may be conducive to the subsequent business performance.

Thus, the purpose is to investigate the described gaps above by testing a structural model including the relation between corporate and external embeddedness of subsidiaries, and the direct and indirect (via subsidiary corporate influence) effects of the two types of embeddedness on innovation-related business performance. Our study contributes to the field of embeddedness and performance: by analyzing and comparing embeddedness of innovations in the corporate and external contexts of subsidiaries, this research sheds light on the respective importance of these contexts. This is of particular relevance also to the field of subsidiary development and the literature on subsidiary roles for competence creation and influence (Holm \& Pedersen, 2000; Foss \& Pedersen, 2002; Birkinshaw, Hood \& Young, 2005; Cantwell \& Mudambi, 2005). Our analysis particularly brings to the fore subsidiary influence as a mediating factor between the embeddedness and performance of innovation, which, to the best of our knowledge, has not been done extensively before.

The results show that corporate and external embeddedness are complementary contexts, although they affect performance differently. Whereas external embeddedness directly affects innovationrelated business performance, corporate embeddedness strengthens the subsidiary's influence within the MNC, which positively relates to performance. The research presented here outlines the difficulty and importance of simultaneously balancing both external and corporate relationships, i.e. dual 
embeddedness, to nurture subsidiaries' innovation projects and capabilities. This has implications for managers' strategic choices for investment in long-term collaboration for innovation in corporate versus external contexts.

The study starts by discussing the theme of innovation and subsidiary embeddedness in the MNC. We then develop a set of hypotheses to explain the relations between corporate and external embeddedness, subsidiary influence over innovation-related investments, and business performance of innovation usage. These hypotheses are tested in a structural model based on a sample of 85 innovation projects taking place in $23 \mathrm{MNCs}$. The investigation ends by drawing conclusions and discussing the managerial implications, together with issues for future research.

\section{INNOVATION AND SUBSIDIARY EMBEDDEDNESS}

This study conceptualizes 'innovation development' as the process of transforming an idea into a completed form that is acceptable to potential adopters, such as customers and corporate sister units. The 'completed form' may be manifested as the change in a process and in the outcome of a process, related to industrial production and/or exchange (Zander, 1991). Innovations can be classified according to many dimensions. The most common typology distinguishes between product, process, and service innovations (von Hippel, 1994). Innovations lead to change or deviation from a firm's existing competencies, which may be described as incremental or radical (e.g., Anderson \& Tushman, 1990; Garcia \& Calantone, 2002). These changes represent novelty in relation to users and are often believed to lie at the heart of competition, economic development, and firms' competitiveness. Hence, there is a relationship between innovation and performance (Cho \& Pucik, 2005; Fiol \& Lyles, 1985; Hertenstein, Platt, \& Veryzer, 2005; Figueiredo \& Brito, 2011). In business terms, the success of an innovation could be manifested as profits, sales, market share, and positioning (e.g., Kessler, Bierly, \& Gopalakrishnan, 2000). For instance, a product innovation could be evaluated through its ability to retain existing customers or attract new ones, because an increase in the quality of a product, or the adoption of a new design or function, is often a determinant in capturing customers. Likewise, an innovation may reduce the costs of a production process and improve a company's competitive ability through better margins. 
Innovation and, increasingly, the management of the innovation process are being recognized as core elements in shaping the competitive advantage of an MNC. A considerable amount of research has been devoted to the study of the managerial side of processes that may lead to innovation. In particular, since innovation is considered a highly strategic tool, many scholars have investigated how specific factors in the context surrounding innovation may shape an innovation and enhance subsidiary innovativeness (e.g., Brown \& Eisenhardt, 1995; Ghoshal \& Bartlett, 1988). MNC researchers often argue that innovative activity increasingly resides in operative subsidiaries, and they also stress the particular importance of the external environment (e.g., Andersson et al., 2002; Frost, Birkinshaw, \& Ensign, 2002; Ghoshal \& Bartlett, 1990). In connection with this, it has been argued that interaction and tight cooperation in the network relationships are fundamental for innovations (von Hippel, 1988). Therefore, a subsidiary's ability to innovate is largely based on the quality of interaction and, consequently, on the depth of its relationships with its counterparts.

The importance of relationships has been discussed in the literature on social networks, which assumes that economic exchange is affected by the history of exchange and the expectations of future exchange (e.g., Granovetter, 1985). Such contextualization of business exchange has been termed embeddedness, which is frequently described as a strategic resource that is important for information, innovation, and power, among other things, and is often separated into the dimensions of structural and relational embeddedness. Whereas structural embeddedness reflects how a firm's relationships are connected in the architecture of the overall network structure (Granovetter, 1985; Simsek, Lubatkin, \& Floyd, 2003; Uzzi, 1997), relational embeddedness emphasizes the quality of the firm's dyadic relationships (Fjeldstad \& Sasson, 2010). In this distinction, research on structural embeddedness often considers the brokering and diffusion of innovations, and the advantage of a position in the network rather than the advantage from exchange in individual relationships (Granowetter, 1992; Moran, 2005).

In line with Granowetter (1985), we adopt a relational understanding of embeddedness, emphasizing that economic behavior is closely embedded in networks of interorganizational relations. As argued above, relational embeddedness is critical for learning processes that are characterized by the exchange of less tangible resources and the development of a shared understanding of innovation 
usage (Gulati, 1998). This is particularly important for entrepreneurial behavior and for explaining innovation-oriented tasks (Brown \& Eisenhardt, 1995; Hansen, 1999; Takeishi, 2001). Embeddedness in relationships, therefore, comprises the development of new knowledge with the potential to create value for the subsidiary, but potentially also for the MNC as a whole, too. In accordance with this view, research on innovation has commonly adopted embeddedness as an explanatory factor in the analysis of innovation development and performance (Bonner, Orville, \& Walker, 2004). During recent years, the concept has also been adopted into studies of the MNC, especially in the fields of knowledge and innovation, often addressing the impact of the subsidiary as a generator of novelty (Figueiredo, 2011; Garcia-Pont, Canales, \& Noboa, 2009; Meyer et al., 2011; Nell, Ambos, \& Schlegelmilch, 2011). Thus, our use of relational embeddedness is aligned with that of researchers who state that such embeddedness influences which resources will be accessed through interaction with other organizations and the extent to which this occurs (Granovetter, 1992; Podolny, 2001; Rowley, Behrens, \& Krackhardt, 2000).

We view relationships as inter-organizational phenomena in the sense that subsidiary managers organize and manage innovations through exchange in the relationships with other corporate organizations (corporate embeddedness) and external business counterparts (external embeddedness). Hence, embeddedness concerns relationships at the organizational level and centers on the innovation development within those relationships. Our focus on innovation is in line with contemporary research, which often separates embeddedness into different dimensions and mechanisms depending on the choice of analytical focus (e.g. Heidenreich, 2012; Zukin \& DiMaggio, 1990). It has, furthermore, been pointed out that embeddedness should be understood as a process in which the actions of agents (i.e. subsidiaries) are not totally determined by the surrounding network (Heidenreich, 2012). This means that embeddedness does not contradict the active role of a subsidiary that also creates its embeddedness through strategic choice and investment in counterpart interaction (Heidenreich, 2012; Garud, Hardy \& Maguire, 2007; Kostova, Roth \& Dacin, 2008). This study thereby focuses on innovation in the context of relational embeddedness: it addresses the development of business related activities, such as the creation of new products or production technologies. Evidently, embeddedness implies the use of resources, as it requires managerial time and investment 
in collaborative arrangements. An actor is, therefore, likely to select relatively few relationship counterparts with which it organizes mutual innovation processes.

This implies that embeddedness will vary across subsidiary relationships and across subsidiaries, depending on the level of available resources, experiences and specific needs. Certain subsidiaries will organize innovations development through embeddedness in corporate relationships, external relationships, or in both contexts (Takeishi, 2001; Tidd, 1995). Although embeddedness reflects the same basic mechanism for innovation in each of the two contexts, the importance of the respective context may vary. In the following, we distinguish between these contexts and argue that the embeddedness in the external and the corporate contexts is associated with the business performance and influence on intra corporate resource distribution of subsidiaries.

\section{DEVELOPMENT OF HYPOTHESES}

\subsection{Embeddedness and Innovation Performance}

Whereas a positive relation between embeddedness and innovation performance has been observed in the literature on innovation, the context of the MNC unfolds a complicated situation where an innovating subsidiary must balance its resource-demanding activities against both its market- and corporate roles. In essence, this means that the deployment of new innovations is potentially affected by the qualities of both the corporate and the external networks. As far as external embeddedness is concerned, it has been argued that the launching of innovations creates uncertainty among related market actors and that embeddedness of an innovating actor in market relationships decreases such uncertainty, since embeddedness increases the mutuality in motivation and the willingness to share information and commit resources to mutual problem-solving (Dyer \& Nobeoka, 2000; Uzzi, 1997). Consequently, external embeddedness decreases the risk of negative market reactions (Simsek et al., 2003 ) as the innovation becomes more achievable among business actors (Pinch et al, 2003). It therefore increases the likelihood of exploiting the innovation and, thus, the potential business performance (Dyer \& Singh, 1998; Lane \& Lubatkin, 1998). However, embeddedness requires investment in mutual technologies, business procedures and learning processes and is therefore not created overnight (Forsgren et al., 2005). Furthermore, it is not a feature that is developed in all 
exchange relations. Subsidiaries will consequently vary in their levels of external embeddedness (Bouquet \& Birkinshaw, 2008; Helble \& Chong, 2004): some will conduct business exchange without committing their business development to deep relationships, whereas others will devote considerable resources into such processes. We argue that the degree to which subsidiary innovation development is embedded in external relationships will influence the subsidiary's ability to incorporate the resulting innovations into its business activities. This is in line with Dyer and Hatch (2006), who argued that network capabilities can contribute to the sustained competitive advantage of firms, as well as Cantwell and Janne (1999) and Andersson et al. (2002), who argued that embeddedness in valuable and competence-rich relationships is a potential source of competitive advantage. This leads to the following hypothesis:

Hypothesis 1a. There is a positive relationship between the external embeddedness of a subsidiary's innovation-related activities and the subsidiary's innovation-related business performance.

According to Garcia-Pont et al. (2009), corporate embeddedness is an overlooked, but relevant, factor for the development of subsidiary-specific advantage. However, whereas these authors deal with corporate embeddedness as by considering it to be the formation of subsidiary strategy, distinguishing between strategic, capability and operational embeddedness, our viewpoint considers corporate embeddedness as an integrating mechanism that creates the awareness and ability to communicate business-related innovation requirements and opportunities. As is the case with external embeddedness, subsidiaries will, to varying degrees, develop specific relationships with corporate counterparts (Tsai, 2001), such as peer units, corporate suppliers, customers, R\&D units and headquarters ${ }^{1}$. We thereby argue that corporate embeddedness will provide subsidiaries access to existing resources within the $\mathrm{MNC}$ and will make it possible to combine capabilities through collaboration (Barney, 1991; Cantwell, 1994; Foss 1999; Kogut \& Zander, 1993). This facilitates

\footnotetext{
${ }^{1}$ Corporate embeddedness is sometimes restricted to the analysis of lateral relationships (see, for example, Forsgren et al., 2005). The present study also includes the subsidiary's relationships with headquarters.
} 
responsiveness vis-à-vis the subsidiary's business-related needs, which is the same mechanism as for external embeddedness. In comparison with external embeddedness, the organizing of innovations through intra-corporate relationships occurs at a distance from the subsidiary's market. We may still assume that the corporate embeddedness provides an innovation-related advantage that can be utilized when implemented in business activities. This reasoning is in line with the finding that intra-firm communication is important for successful product innovation (Fidler \& Johnson, 1984; Hillebrand \& Biemans, 2004; Schulz, 2003) and for the adoption of innovations by subsidiaries (Ghoshal \& Bartlett, 1988). This is also consistent with Monteiro, Arvidsson, and Birkinshaw (2008), who found a strong positive relation between a subsidiary's level of knowledge exchange in the MNC and the subsidiary's financial performance. Further, Ciabuschi, Dellestrand and Martín Martín (2011) found that corporate embeddedness, brought about through the involvement of headquarters during the innovation development, was positively related to innovation outcomes that strengthen the competitive advantage of a subsidiary.

We conclude that the corporate embeddedness of subsidiaries during innovation development is positively associated with the subsidiary's innovation-related business performance.

Hypothesis $1 \mathrm{~b}$. There is a positive relationship between the corporate embeddedness of a subsidiary's innovation-related activities and the subsidiary's innovation-related business performance.

\subsection{Embeddedness, Subsidiary Influence and Innovation Performance}

The role of subsidiary influence within the MNC where innovation-related performance is concerned will be discussed in two steps: we first discuss the relationship between external and corporate embeddedness and subsidiary influence, respectively, and then we consider the relation between subsidiary influence and innovation performance.

The external embeddedness of subsidiaries has been increasingly addressed as a managerial issue in the literature on MNCs (Meyer et al., 2011; Nell et al., 2011). In the present study, we argue that when the innovations of a subsidiary are embedded in external relationships, it holds a bridgehead 
position between the MNC and the external network. The subsidiary's exclusive access to the competences and processes of innovation development in external relationships are resources that create a dependence on the subsidiary of the rest of the MNC and its headquarters, which improves the ability of a subsidiary to exercise influence on corporate decisions (Andersson et al., 2007; Bouquet \& Birkinshaw, 2008). This is in line with the resource-dependence theory, in which an actor's control over resources that are of importance for others is the basis for that actor's ability to influence corporate decision-making (Anderson \& Narus, 1990; Astley \& Sachdeva, 1984). Hence, it may be essential for the subsidiary to exercise its influence over the resource distribution because innovations often require technological and organizational adjustments that are directly associated with increasing costs. In connection to this, we argue that the extent to which innovations stem from external relationships controlled by a particular subsidiary could determine the extent to which headquarters would be expected to pay attention to that subsidiary (Bouquet \& Birkinshaw, 2008; Ocasio, 2011). This will lead to a deeper headquarters-subsidiary relationship with greater exchange of information between the two managerial levels (Lane \& Lubatkin, 1998). In this way, the managerial relationship between headquarters and the subsidiary provides a gateway to knowledge about innovation development, which in itself creates a basis for bargaining power in rent-seeking negotiations (Cantwell \& Mudambi, 2005; Mudambi \& Navarra, 2004). Based on headquarters' recognition of the subsidiary's innovation capability in external relationships, then, the subsidiary can have a voice and engage in political games (Casciaro \& Piskorski, 2005; Medcof, 2001). In accordance, prior research has argued that external embeddedness is a criterion that a company's headquarters may use when selecting which subsidiaries to concentrate its managerial effort upon (Andersson et al., 2007).

Hence, the inherent influence of a subsidiary is based on its control over innovation processes in its relationships and in the headquarters' understanding of the development of innovative activities in those relationships (Forsgren \& Holm, 2010; Medcof, 2001), as well as the fact that the position of the subsidiary cannot be easily altered (Pfeffer \& Salancik, 1978). This conclusion is consistent with the seminal article by Ghoshal and Bartlett (1990), which suggested that the density of exchange relationships with local partners is an important basis of subsidiary power. They argued that, as the subsidiary is the link to external resources of this type, it has a strong base from which to exercise 
influence over the internal resource distribution within the MNC. Therefore, we argue that the extent to which the external embeddedness of a subsidiary supports the development of critical capabilities for innovation is positively associated with the subsidiary's ability to influence innovation-related decisions.

Hypothesis 2a. There is a positive relationship between the external embeddedness of a subsidiary's innovation-related activities and the subsidiary's influence over innovation-related decisions in the MNC.

The above reasoning is essentially also valid for corporate embeddedness. To the extent that a subsidiary's innovations are embedded within the corporate network, it plays an integrated role of strategic importance. In comparison with the external embeddedness, it signifies less of a bridgehead position, since it concerns corporate relationships. In contrast with external embeddedness, under normal circumstances, we can expect headquarters to have its own relationships with the corporate actors with which the subsidiary has relationships, and to possess greater knowledge of the mutual innovation processes. This important integrated role relates to the literature on research into centres of excellence, which basically suggests that subsidiaries that are able to manage knowledge and competence flows with the purpose of innovation will generate strategic roles within the corporate network and have an increased influence over investments and resource allocation (Frost et al., 2002). We thereby assume that there is a connection between the corporate embeddedness of a subsidiary's innovation process and its ability to acquire and distribute relevant knowledge within the corporation, and thus to gain attention from headquarters (Bouquet \& Birkinshaw, 2008). In consequence, the corporate embeddedness of subsidiary innovation increases the dependence on the subsidiary, which strengthens the subsidiary's ability to influence innovation-related decisions. This has also been expressed as the 'strategic embeddedness' of a subsidiary (Garcia-Pont et al., 2009). Thus, we formulate the following hypothesis: 
Hypothesis $2 \mathrm{~b}$. There is a positive relationship between the corporate embeddedness of a subsidiary's innovation-related activities and the subsidiary's influence over innovation-related decisions in the MNC.

We now turn to the effect of subsidiary influence on innovation performance. To the extent that headquarters is a recipient of influence from several resource-demanding subsidiaries, it might need to prioritize its innovation prospects. As argued above, innovations may be associated with uncertainty about potential applications, and, therefore, also with difficulties predicting market potentials.

Considering this, the distribution of resources to sanction a subsidiary innovation can be associated with risky prospects because of the considerable effort and the costs associated with overcoming the structural inertia, both within and outside the MNC (Simonin, 1999; Teece, 1977). Still, the ability of a subsidiary to generate additional resources by influencing corporate decisions can be conducive for the integration of an innovation into business operations and may represent a strong potential for improved business performance. Such resources can allow for innovation-related investments in products, production, and marketing procedures or organizational changes, which enhance the implementation of an innovation and the subsequent business performance. In fact, the adoption of an innovation may take time and require considerable resources, especially when innovations are unique and require adaptation among network actors (Hallin et al., 2011). Stieglitz and Heine (2007) found that when the requisite complementary resources are in place, firms are better able than their competitors to engage in internationally generated growth from their innovations. Therefore, we propose a positive link between the influence a subsidiary has on the distribution of MNC resources for innovation-related investments and the business performance of the innovations.

Hypothesis 3. There is a positive relationship between the subsidiary's influence over the innovation-related decisions in the MNC and the subsidiary's innovation-related business performance.

\subsection{Subsidiary External and Corporate Embeddedness}


An important factor in the analysis is the degree of interrelation between external and corporate embeddedness in the development of an innovation. The two contexts can be interpreted as a dual role of the subsidiary. Although both roles are driven by business exchange, the corporate role is also influenced by administrative and strategic 'obligations' that arise because it belongs to an MNC (Kogut \& Zander, 1993; Porter \& Fuller, 1986). We proceed with the association between external and corporate embeddedness and consider whether these are complementary or subject to a trade-off ${ }^{2}$.

One could argue that the more a subsidiary is embedded in the corporate network for its innovation, the less it needs to engage in external relationships, and vice versa. The subsidiary may also face different and incompatible business interests within the two networks, which can create a dilemma in that the impact stemming from external and corporate embeddedness can emerge in a conflict (Forsgren et al., 2005). When the embeddedness exists in both networks, i.e. dual embeddedness, the subsidiary must manage and combine the interests stemming from corporate and external activities to ensure that it pursues consistent goals. This may require considerable resources for coordination, and to handle problems associated with the adoption of the innovation among both corporate and external actors (Helble \& Chong, 2004). In some cases, when manifold actors in the corporate and external environment are concerned with the development activities, the coordination costs may become prohibitively large. In order to keep these coordination costs at a reasonable level, the subsidiary may have to focus its innovation processes on the concerns of relationships either within the MNC or external to it. In considering sources of knowledge, Gammelgaard and Pedersen (2010) found that subsidiaries use external knowledge to a lesser degree if they rely heavily on internal knowledge. Their explanation was based on the argument that the MNC and the external network constitute two institutional obstacles: the more a subsidiary relies on one context, the fewer the resources that might be made available to engage in the other. Therefore, devoting resources to innovative activities through embedded relationships in one context will mean that limited resources can be distributed to

\footnotetext{
${ }^{2}$ In the following paragraphs, we propose a negative and a positive relation between external and corporate embeddedness. Figure 1 portrays this as a link in which external embeddedness affects corporate embeddedness, although the causal direction of the relation may be reversed. The effect of this relation, including an interpretation of the reverse direction, is commented in the concluding section on pp. 25 .
} 
innovative activities within the other. On this basis, a negative relation is expected between corporate and external embeddedness with regard to the development of any particular innovation.

Hypothesis $4 a$. There is a negative relationship between the external embeddedness and the corporate embeddedness of a subsidiary's innovation-related activities.

Another line of reasoning is that the legal boundary of an MNC does not divide the network of a subsidiary into two distinct contexts (Asakawa, 2001; Helble \& Chong, 2004), especially when considering a single function (namely, innovation development). For the purpose of innovation, then, the corporate border may not have a boundary effect, which may enable a subsidiary to develop a high degree of corporate embeddedness while still being embedded in the external business network. This may actually be necessary, as subsidiaries sometimes need to combine their resources and competences with those in other parts of the MNC in order to support their external activities, and vice versa (Cantwell, 1994). This is likely when the subsidiary's corporate and external business networks are interdependent; that is, when the networks are connected in such a way that changes in the activities in external relationships introduce changes in corporate ones, or vice versa (Cook \& Emerson, 1978). The stronger the interdependence, the more likely it is that the activities in the corporate and external business networks will be shaped to ensure 'consistency'. Embeddedness in both contexts will be important as it facilitates the diffusion of information throughout the network and provides a better insight into entrepreneurial action (Simsek et al., 2003). What counts, therefore, is how relationships are connected through, for instance, knowledge and resource exchange, rather than whether they are kept apart by the legal border of the firm. We propose that subsidiaries that pursue innovative roles in the MNC will consider the consistency between the corporate and external network. Cassiman and Veugelers (2006) and Frenz and Ietto-Gillies (2009) made similar arguments, finding support for a positive effect on innovative performance through complementarities between internal and external networks. Thus, we formulate the following alternative hypothesis: 
Hypothesis $4 \mathrm{~b}$. There is a positive relationship between the external embeddedness and the corporate embeddedness of a subsidiary's innovation-related activities.

Figure 1 presents and summarizes the hypothesized relationships between the constructs.

("Figure 1 about here")

\section{METHODS}

\subsection{Sample and Data Collection}

We investigated 85 innovations developed in 63 subsidiaries in 31 business divisions belonging to 23 MNCs. Each MNC had between one and five divisions, while each division had between one and 11 subsidiaries. The firms in the sample represented different industries. Based on the International Standard Industries Classification (ISIC), the 63 subsidiaries can be classified into seven main groups: forestry and logging (6 subsidiaries); manufacture of food products (4); manufacture of paper and paper products (18); manufacture of computer, electronic, and optical products (4); manufacture of machinery and equipment n.e.c. (21); manufacture of motor vehicles, trailers, and semi-trailers (5); and telecommunications (5).

The 85 innovations investigated were developed and released by subsidiaries between 1990 and 2004. The subsidiaries all performed their own development of the innovations included in the investigation that they subsequently used in their own business activities. One important criterion when choosing innovations to study was that they must have been used in process or marketing activities for at least one year; this ensured that managers had sufficient experience of the effects of the innovations on business performance. On average, 1.3 innovations were studied in each subsidiary, although the number varied between one and five depending on access to information. The subsidiaries were located in 14 countries, with Swedish subsidiaries accounting for 38.8 percent of the innovations. The remainder were released by subsidiaries in Taiwan (18.8 percent); Italy (8.2 percent); France and the United Kingdom (7.1 percent each); Belgium, Finland, Germany, and the United States (3.5 percent each); and Austria, the Czech Republic, Denmark, the Netherlands, and Switzerland (1.2 
percent each). On average, the subsidiary size was 571 employees, sales were 281 million Euros, the age of the subsidiary was 48 years, and the R\&D budget was approximately 8 million Euros.

We used purposive sampling to select MNCs that were greatly involved in technological development from advanced economies where the gross domestic expenditure on $R \& D$ is high. Initially, the MNCs were sent a formal letter asking them to participate in the study. A first meeting was usually held at the HQ level, with the objective of becoming acquainted with the organization and asking for potential respondents at the subsidiary level. Managers of the subsidiary (or divisional HQs) were then asked to identify innovations to be studied. The next step - choosing which subsidiary relationships to study - was critical, given the focus on corporate and external embeddedness of subsidiaries. We had to limit the number of relationships to be investigated, as it would not have been possible to gather information about every kind of relationship that every subsidiary has, especially as the study required face-to-face interviews in many countries. Therefore, for practical and analytical reasons, the investigation of subsidiary embeddedness was limited to concern a number of each subsidiary's relational counterparts (such as customers, suppliers, and other corporate units). The respondents were asked to describe and assess up to six relationships that had been associated with innovation development. This meant that relationships were selected with regard to their importance for innovation without considering the degree of embeddedness. Indicators of embeddedness were then measured by asking the managers to characterize the relationships using our structured questionnaire. Hence, we wanted to capture the degree of embeddedness of relationships that had been important for innovation development. The respondents were also asked to indicate whether the relationship in question was external to or within the MNC. Out of 268 relationships identified, 121 (45 percent) were external and 147 (55 percent) were internal to the MNC. These different sets of relationships (external and corporate) are used in the analysis of the subsidiary external embeddedness and corporate embeddedness.

The data collection was carried out between 2002 and 2005 by nine researchers who visited the different countries in which the subsidiaries were located. Through face-to-face interviews, the interviewer was able to interact with the respondents - usually $R \& D$ managers, project managers, and subsidiary CEOs in charge of innovation projects and/or extensively involved in the innovation 
development and/or transfer process - and clarify the questions when necessary. Each interview lasted for between two and four hours and some were complemented by a visit to the facilities and a practical demonstration of the innovation in question. The data was collected using a structured questionnaire and all the interviews were in English. The managers and CEOs were proficient in this language. To increase face validity, a qualitative pre-test was carried out by means of two pilot interviews with MNC managers. Minor changes were made in order to correct ambiguous questions and phrasing and to enhance the applicability of indicators.

\subsection{Measures}

\subsubsection{External and corporate embeddedness}

Two aspects of embeddedness - 'external' and 'corporate' - were measured in the sampled relationships. Firstly, external embeddedness considered the depth of business-related activities within those external relationships. This was measured by asking respondents about (i) the extent to which there was closeness in the business relationship in terms of sales and purchase of goods and services, (ii) the degree to which the subsidiary had adapted its resources and activities to the specific counterpart, and (iii) whether the counterpart had been important for the subsidiary's business for a long time (see Appendix A). These measures are similar to previous studies that have dealt with external embeddedness of a business actor (see, e.g., Andersson, Forsgren, \& Holm, 2001). Secondly, corporate embeddedness was operationalized to capture the subsidiary's embeddedness with MNC headquarters and peer units. Two indicators were used for embeddedness in the subsidiary-HQ relationship, and one other indicator concerned the embeddedness of relationships with peer units. The indicators are: (i) headquarters' support for the interests of the subsidiary in developing the innovation, (ii) the frequency of interaction in cooperation with headquarters, and (iii) the temporal importance of the corporate counterpart for the business of the subsidiary (see Appendix A).

Two seven-point Likert-type scales were used for each construct, ranging from 1 (totally disagree) to 7 (totally agree). To assess measures of external and corporate embeddedness on the "subsidiaryrelationship level', the scores on the embeddedness items in each of the two sets of relationships 
(external and corporate) were added together and then divided by the number of external and corporate relationships, respectively.

\subsubsection{Subsidiary influence}

Our measure of subsidiary influence concerns the position of the subsidiary in relation to the HQ and the rest of the corporation. It is generally accepted that technological knowledge is an important part of a firm's competitive strategy (Porter, 1983) and that technological development is reflected in the development of products and production processes (Ghoshal \& Bartlett, 1988). Three indicators were adapted to measure subsidiary influence and a seven-point scale from -3 to +3 (the extremes corresponding to strong negative influence and strong positive influence, respectively) was used. Firstly, interviewees were asked to evaluate how the innovation had affected the unit's position; this was done by asking about (i) the subsidiary's advantage within the MNC in comparison to other corporate units. Secondly, in line with the above-mentioned previous studies on technological knowledge, we posed questions concerning the extent to which the innovation had positively affected the subsidiary's influence concerning decisions about investments in the subsidiary's (ii) production capability and (iii) R\&D (see Appendix A).

\subsubsection{Business performance}

The literature includes a long tradition and debate about measuring performance (March \& Sutton, 1997; Richard et al., 2009). Subsidiary business performance encompasses profits and business volume, as well as overall competitive advantage as the outcome of, for instance, improved market share, positioning, and image (Brown \& Eisenhardt, 1995; Ettlie, Bridges, \& O'Keefe, 1984; Hitt et al., 1996). In the present study, the indicators of the 'business performance' construct account specifically for the impact that the innovation has on the subsidiary's business (see Appendix A). Thus, the business performance of the subsidiary was not considered as a whole; we only considered the perceived influence of using a particular innovation in business-related activities. Other studies have employed similar types of assessment for business performance (e.g., Tracey, Lim, \& Vonderembse, 2005; Yamin et al., 1997) and shown that the approach can yield useful insights. This is 
an important distinction, not only because it makes it possible to study the phenomenon under consideration more readily, but also because it requires sound indicators of the actual influence of the innovation on the market-associated subsidiary activities. Consequently, innovation-related business performance is typically measured in terms of sales growth, market share, and profitability (Prajogo, 2006; Prajogo \& Ahmed, 2007). Following this, we first asked the subsidiary manager and/or the manager of the innovation project to estimate the extent to which the innovation had affected (i) the unit's business volume in the local market, (ii) its competitive advantage on the market, and (iii) its operating profit. A seven-point scale spanning from -3 to +3 (corresponding to the strong negative and strong positive impact) was used for the three items capturing the business performance construct.

\subsubsection{Controls}

We included a control for the size of the firm, measured in terms of the number of employees in the subsidiary, to eliminate any size-related effects on the endogenous constructs. For example, subsidiary influence may differ between large and small subsidiaries. We also controlled for the industry to which the subsidiary belongs according to the classification in seven groups presented above. Given that some subsidiaries belong to the same division/business area and MNC, we also controlled for both the division and the MNC. Furthermore, innovation brings about a certain degree of novelty and a need for adaptation among market actors, which may improve or decrease the performance of the business. In so doing, we controlled for the 'magnitude' of the innovation by estimating the development cost (determined by asking whether, to develop the innovation, the interviewees had had to invest significantly in skilled human resources and specialized equipment and facilities). The two questions were measured on a seven-point scale $(1=$ not at all, $7=$ very much). For the same reason, we also controlled for the type of innovation, indicating the relevance of product, process, marketing, and core technology innovations in the form of four dummy variables. Finally, we entered a control for the time since the innovation was released; this was done since older innovations may have a higher effect on innovation-related subsidiary influence and business performance than the newer ones. 


\subsubsection{Common method variance}

We followed a double strategy to deal with common method variance, given that the data on the exogenous and dependent variables were going to be collected from the same respondents (Chang, Witteloostuijn, \& Eden, 2010). On one hand, the design of the study enabled the constructs and their items to be spread out in the questionnaire and separated by other questions. Furthermore, the indicators reflecting the constructs business performance and subsidiary influence appeared earlier in the questionnaire than the measures of corporate and external embeddedness and there was therefore no obvious connection between these questions. In addition, the indicators were anchored in two different scale ranges (-3 to 3 and 1 to 7 ) and we used two response formats (totally disagree-totally agree and strong negative effect-strong positive effect). On the other hand, we performed a Harman's one-factor test as a post hoc statistical procedure with the intention of testing common method variance (Podsakoff \& Organ, 1986). The results of a principal components analysis generated four un-rotated factors with eigenvalues over 1 and explained 65.6 percent of the variance (between 25.8 and 9.3 percent). Twelve factors were required to explain 100 percent of the variance. Next, a theoretically unrelated marker variable ('Informal communication channels make you aware of your performance relative to other units') was used and this surrogate was used to statistically control for method variance (Podsakoff et al., 2003). We only found marginal effects on the structural parameters and did not observe any change in their significance. Both statistical procedures, together with the research design, suggest a low risk associated with this potential problem.

\subsection{Data Analysis Method}

The data analysis was conducted using the Partial Least Squares (PLS) method (Wold, 1982). PLS is a second-generation multivariate analysis technique (Fornell, 1982). Apart from the research objectives and the exploratory nature of the investigation, this variance-based Structural Equations Modeling (SEM) technique was preferred over covariance-based ones because of the small sample size and the non-normal distribution of most of our indicators. According to Fornell and Bookstein (1982: 440), 'it avoids many of the restrictive assumptions underlying maximum likelihood techniques and ensures against improper solutions and factor indeterminacy.' 


\section{ANALYSIS}

We analyzed and interpreted the structural (SEM-PLS) model in two steps. In the first step, we evaluated the reliability and validity of the measurement model; in the second step, we tested the structural model (Hulland, 1999). Table 1 reports the statistics for the individual loadings (the item reliability values) for the measurement model. All correlations between constructs and items were statistically significant and over the minimum acceptance threshold of 0.50 (ibid.). Nevertheless, 'Perf3' (0.62) and 'Influen1' (0.69) are below the more reliable cutoff point of 0.70. However, their loadings have highly significant t-values $(5.50$ and 5.87 respectively, $\mathrm{p}<0.001)$ and their constructs' Average Variance Extracted (AVE) are clearly above the suggested 0.5 level. In view of these results, we preferred to retain both indicators in the operationalization of their respective constructs.

\section{("Table 1 about here")}

Construct reliability is presented in the third column of Table 1 . Composite reliability values (Werts, Linn, \& Jöreskog, 1974) are over the suggested bounds, ranging between 0.77 for 'corporate embeddedness' and 0.81 for 'subsidiary influence'. Convergent validity was tested using the measure of the construct variance associated with its indicators or AVE (Fornell \& Larcker, 1981), with values clearly over the 0.5 threshold. Finally, regarding the discriminant validity of the constructs, Appendix B reveals that the constructs and measures are well within the accepted range of values for the conditions to be met. At this point, therefore, it was possible to state that the measures are reliable and valid $^{3}$

We continued the analyses by testing the structural model, which includes the hypothesized relationships. Several paths are statistically significant as shown by a 500 sub-sample bootstrap. These are the relationships between 'external embeddedness' and 'business performance' (H1a); 'corporate embeddedness' and 'subsidiary influence' (H2b); 'subsidiary influence' and 'business performance'

\footnotetext{
${ }^{3}$ Also, the 'development cost' control demonstrated good metric properties: item reliabilities $=0.87$ and 0.86 ; composite reliability $=0.86 ; \mathrm{AVE}=0.75$.
} 
(H3), and external embeddedness' and 'corporate embeddedness' (H4b); However, the relations associated with hypotheses $\mathrm{H} 2 \mathrm{a}(\beta=-0.10, \mathrm{p}>0.1)$ and $\mathrm{H} 1 \mathrm{~b}(\beta=0.03, \mathrm{p}>0.1)$ were not empirically supported, and were consequently dropped. Only the significant relationships were retained for a second round of estimation. This second test provided significant relations for all of the remaining paths (see Figure 2).

("Figure 2 about here")

("Table 2 about here")

Considering the results in greater detail, the analysis supports Hypothesis 1a (see Table 2), which indicates that the embeddedness of a subsidiary's innovation on its external relationships is positively associated with the innovation-related business performance $(\beta=0.30, \mathrm{p}<0.05)$. Interestingly, corporate embeddedness was not found to have a similar effect, which means that Hypothesis $1 \mathrm{~b}$ is not supported, as pointed out above. Hypothesis 3 is supported $(\beta=0.31, p<0.01)$, which indicates that business performance is positively associated with the subsidiary's ability to influence headquarters' innovation-related investment decisions (see Table 2).

The analysis further shows that external embeddedness does not directly affect the subsidiary's ability to influence innovation-related investment decisions. Hence, no support was found for Hypothesis 2a whilst Hypothesis $2 \mathrm{~b}$ was supported (see Table 2), since corporate embeddedness is positively related $(\beta=0.23, p<0.05)$ to subsidiary influence. Furthermore, the support for Hypothesis $4 \mathrm{~b}(\beta=0.39, \mathrm{p}<0.01)$ (but not for $4 \mathrm{a})$ indicates a positive link between external and corporate embeddedness ${ }^{4}$; this suggests that a subsidiary combines corporate capabilities with external capabilities for the purpose of innovation development (see Table 2). Finally, the indirect effect of corporate embeddedness on innovation-related business performance can be quantified as 0.07 .

The analysis also reveals some significant effects of two control variables (see Table 2). Firstly, the magnitude of the innovation in terms of development cost is positively associated with the subsidiary's

\footnotetext{
${ }^{4}$ The statistical results for the hypothesized model are identical to those obtained when the relationship is reversed in the specified model and tested as corporate embeddedness influencing external embeddedness.
} 
ability to influence corporate decisions $(\beta=0.39, \mathrm{p}<0.001)$. Hence, subsidiary influence is not only affected by the corporate embeddedness of innovation development, but it is also related to the magnitude of the innovation per se. Secondly, process innovation is the only type of innovation that seems to affect the model. This type of innovation is negatively associated with the business performance of the subsidiary's innovation $(\beta=-0.30, \mathrm{p}<0.01)$, which indicates that the adoption of new production processes may be more risky than other types of innovation. However, the control for subsidiary size and the time (duration) since the innovation was released had no significant effect on the endogenous constructs. Finally, the industry in which the subsidiary operates and the division and MNC to which it belongs - which were tested using a jack-knifing procedure in which we iteratively excluded an industry (division/MNC) - confirmed the stability of the parameter estimates.

Table 2 also shows the level of variance explained, and the Stone-Geisser $Q^{2}$ for the resulting structural model. Firstly, with respect to the quantity of variance explained by the model $\left(\mathrm{R}^{2}\right)$, PLS provides the following values: 0.243 for 'business performance'; 0.222 for 'subsidiary influence' and 0.153 for 'corporate embeddedness'. The Stone-Geisser $Q^{2}$ statistics for the predictive relevance of the dependent constructs (Stone, 1974), which were estimated by fixing the omission distance at six observations for the blindfolding technique, is negative for the three endogenous constructs. This technique assesses the validity of the paths by repetitively estimating the model parameters with random data points omitted (that is, taking what is known as hold-out samples). The negative crossvalidated redundancies suggest that other constructs that were not included in the model could explain part of its variance. This is a natural consequence of the fact that our purpose was not to identify the determinants of the endogenous constructs to our best ability, but to test a set of relations between the constructs included in the specified model.

\section{CONCLUDING DISCUSSION}

\subsection{Discussion of the findings}

This study has investigated how the embeddedness of subsidiaries during innovation development affects the performance of innovations. Whereas there is a general postulation that embeddedness is conducive for knowledge exchange and innovation-related activities, the adoption of embeddedness in 
prior studies of the MNC has revealed little understanding about the difference in effects of the external and corporate embeddedness of subsidiaries. Moreover, although subsidiary influence over corporate decisions has been an integral part of the research on subsidiary roles in the MNC, only a few studies have related this to the issue of embeddedness and performance. The present study, therefore, answers to the call for research on subsidiary dual embeddedness and has done so by investigating the relations between corporate and external embeddedness and, via the subsidiary's influence on corporate decisions, the business performance of innovations.

The results confirm that the distinction and inclusion of corporate and external embeddedness of subsidiary innovations is conducive to the analysis of business performance. We find that the innovation-related business performance is positively associated with the external embeddedness of innovation development. The logic is that when subsidiaries become embedded within a network in which they also conduct business, they are better able to evaluate the needs and requirements of their business counterparts, and they will share innovation-related interests to a higher extent. This is in line with findings of such authors as Andersson et al. (2002) and Peng and Luo (2000). However, it is in contrast with studies that have reported: a negative association between relational embeddedness and firm performance (Rowley et al., 2000) or that innovations may be profitable even if they are not adapted to external requirements (Szulanski \& Jensen, 2006). The test also showed that corporate embeddedness had no direct effect on innovation-related business performance, however, it does appear that corporate embeddedness is a predictor of subsidiary influence (while external embeddedness is not significantly related to subsidiary influence), which in turn is positively related to business performance. The rationale of the second effect is that the possibility of the subsidiary to collect resources for innovation-related investments within the MNC organization will improve the innovation implementation and its subsequent business performance.

These findings indicate that corporate and external embeddedness differ in their effects on business performance. While we only can speculate why this is the case, it can be argued that external embeddedness is closely associated to market actors, who through their embeddedness with the subsidiary are an integral part of its innovation development and will consequently be committed in the adoption of the innovation and its related business exchange. Although corporate embeddedness 
may also account for evaluations of needs and requirements of subsidiary business counterparts, it does not directly involve market customers and other external actors. Hence, when an innovation is launched without external embeddedness as a driving feature, the subsidiary's knowledge generated from market relationships is less insightful.

The results are also interesting in relation to the literature on the subsidiary's role in the MNC. Prior research has essentially indicated that subsidiaries sometimes become new centers in the creation and distribution of knowledge within the firm, and that they may exercise an influence over corporate decisions. There seems to be consensus on the fact that such subsidiaries often generate critical knowledge through external relationships. Our findings bring a more detailed picture: external embeddedness is not directly related to subsidiary influence over the distribution of resources, whereas corporate embeddedness is, and serves as an indirect driver of innovation-related business performance. Hence, the strength of the subsidiary's influence is closely associated to its corporate embeddedness. Although external embeddedness is essential for the business performance of an innovation, the generation of internal resources is correspondingly important and corporate embeddedness is an essential factor behind this. The subsidiaries that are able to hold a strong position of both external and corporate embeddedness are probably in a favorable situation.

Moreover, the intriguing observation that external and corporate embeddedness are positively associated suggests that subsidiaries sometimes combine corporate capabilities with external ones for the purpose of innovation development (Cantwell, 1994). There seems to be a rationale in creating close and cooperative relationships on both sides of the legal border of the MNC, which contradicts the view that the external and corporate embeddedness are merely in conflict with one another or subject to a trade-off between them, and thereby pose a managerial dilemma (Heble \& Chong, 2004; Gammelgaard \& Pedersen, 2010; Meyer et al., 2011). The study presented here suggests that the interplay between external and corporate embeddedness plays an important role. A subsidiary that suffers from weak influence over resource distribution may find it meaningful to purposefully manage the connections between internal and external relationships. Moreover, we can posit that embeddedness in only one of the two contexts may provide insufficient variation of supporting capabilities for innovation development. Forsgren et al. (2005), Foss (1999), and Richardson (1972) 
all noted that effective cooperation requires some knowledge of 'neighboring' capabilities, brought about by cooperative relations between firms that need access to complementary, but dissimilar, capabilities. This may require the creation of embedded relationships across corporate borders. In brief, the study contributes to the somewhat indistinct assumption of the relation between embeddedness and innovation performance, uncovering the relevance of the dual contexts of embeddedness. The complementarity of the subsidiary's corporate and external networks provides a more fine-grained and multifaceted picture, where the innovation performance is directly related with external embeddedness and indirectly related with corporate embeddedness via the influence on the innovation investments of the subsidiary. Hence, dual embeddedness of subsidiaries is important for innovation performance although the external and corporate contexts affect performance differently. However, as we cannot determine the direction of causality between external and corporate embeddedness we must stress that the interpretation of the respective importance of the two contexts may be somewhat more complex. As there is a positive relation between these constructs it is not unreasonable that corporate embeddedness also may relate to business performance, indirectly, via external embeddedness. This addresses the question of business performance not being solely related to the external embeddedness of an innovation but also relying on the aligned development activities within the embedded corporate network. Likewise, acknowledging a positive relation between external and corporate embeddedness may mean that external embeddedness has an indirect positive effect on subsidiary influence via corporate embeddedness. Hence, when a subsidiary controls competences for innovation development external to the MNC it may affect the embeddedness of innovation within the corporate network, which indirectly strengthens its ability to exercise influence on corporate investments for innovation. In any case, the positive association between the external and corporate embeddedness is an intriguing observation that signifies the use of complementary resources across the corporate border.

The study was subject to some limitations. One limitation is that we did not use probability sampling, which means that any generalization must be made carefully. Future studies should use probability sampling so that we can generalize our findings to the population of firms developing and transferring innovations. However, we also consider the sample and data to be a strength of the study 
given (i) that assuming a medium effect size (Cohen, 1998), our model would require a minimum sample size of 76 observations (and we have 85 ) to obtain a power of 0.80 and an alpha level of 0.05 , (ii) the considerable variance encountered in terms of the innovations and subsidiaries researched, and (iii) the meticulous personal interviews conducted by the research team. Another limitation, which is also common to most research in the field, concerns the cross-sectional nature of the study, which inhibits the ability to make causal inferences between the different exogenous and dependent constructs tested in the model. It should be stressed, however, that the constructs embrace a built-in time lag: the business performance and influence concern the subsequent usage of the innovation, whereas the constructs of embeddedness are related to the preceding innovation development.

\subsection{Managerial implications and future research}

The results have some managerial implications, particularly concerning the role of headquarters' managers given that the subsidiaries exert their influence on the headquarters. We can stress that the influence of the subsidiary is essential to the business performance of innovations and that corporate embeddedness is a driving factor explaining why headquarters will distribute resources for innovation to certain subsidiaries. However, the study does not reveal whether the influence exercised by the subsidiary is contradictory to the interests of headquarters, or whether it only reflects the fact that corporate embeddedness of subsidiary innovations makes headquarters less ignorant about the needs of the subsidiary - and consequently more willing to meet those needs.

This highlights a managerial dilemma when MNCs contain many innovative subsidiaries, which both provides opportunities and necessitates the introduction of cost considerations (Uzzi, 1996). On the one hand, if headquarters pays attention to many subsidiaries, it will enhance its learning about ongoing innovations. This may be beneficial to the individual subsidiary, but it would mean extensive efforts and managerial costs. Still, our study shows that corporate embeddedness, including the headquarters-subsidiary relationship, enhances subsidiary influence, which is conducive for effective investment decisions that, in turn, have a positive impact on the business performance of subsidiary innovations. Consequently, there is reason to stress the dilemma of how headquarters manage their subsidiary relationships during innovation processes and how they select the projects that they support 
(Bouquet \& Birkinshaw, 2008; Ciabuschi, Forsgren, \& Martín Martín, 2012; Forsgren \& Holm 2010; Mudambi \& Navarra, 2004). This is an area for future research.

Another implication for management and future research concerns the embeddedness of subsidiaries in both external and corporate contexts. Subsidiary resources are probably limited, which suggests that some subsidiaries might prioritize corporate embeddedness, gaining headquarters' attention and striving to influence the resource distribution. Other subsidiaries will prioritize collaboration in external embeddedness instead. However, although our study identified a correlation between the two contexts, we lack knowledge about the complementarity between them and how subsidiaries invest in order to balance their impact. Extended embeddedness across corporate borders requires alignment between both corporate and market-related interests, which is probably a task requiring extensive coordination. Prior research has indicated that many subsidiaries are embedded in either corporate or external relationships, with only few (less than ten percent) being highly embedded in both contexts (Forsgren et al., 2005, pp. 115). This is valid for the configuration of corporate and external embeddedness in the present study, too, in which 10-20 percent of the innovations were highly embedded in both contexts. Hence, it seems that the potential for positive effects to arise from the combination of corporate and external embeddedness are not sought by many subsidiaries. The infrequency of dual embeddedness could, perhaps, be explained by the dilemma that mangers do not realize the collaborative capabilities across corporate and external relationships until the level of embeddedness is considerable (Dyer \& Sing, 1998; Dacin, Beal, \& Ventresca, 1999). Further research should investigate corporate and external embeddedness as complementary contexts for innovation and the restrictions for development of this kind in more detail. 


\section{REFERENCES}

Achcaoucaou, F., Miravitlles, P., \& Leon-Darder. F. (2013). Knowledge sharing and subsidiary R\&D mandate development: A matter of dual embeddedness. International Business Review. http://dx.doi.org/10.1016/j.ibusrev.2013.08.006

Almeida, P., \& Phene, A. (2004). Subsidiaries and knowledge creation: The influence of the MNC and host country on innovation. Strategic Management Journal, 25(8-9), 847-864.

Anderson, J. C., \& Narus, J. A. (1990). A model of distributor firm and manufacturer firm working partnerships. Journal of Marketing, 54(1), 42-58.

Anderson, P., \& Tushman, M. L. (1990). Technological Discontinuities and Dominant Designs: A Cyclical Model of Technological Change. Administrative Science Quarterly, 35(4), 604-633.

Andersson, U., Forsgren, M., \& Holm, U. (2001). Subsidiary embeddedness and competence development in MNCs: A multi-level analysis. Organization Studies, 22(6), 1013-1034.

Andersson, U., Forsgren, M., Holm, U. (2002). The strategic impact of external networks: Subsidiary performance and competence development in the Multinational Corporation. Strategic Management Journal, 23(11), 979-996.

Andersson, U., Forsgren, M., \& Holm, U. (2007). Balancing subsidiary influence in the federative MNC: a business network view. Journal of International Business Studies, 38(5), 802-818.

Asakawa, K. (2001). Evolving headquarters-subsidiary dynamics in international R\&D: the case of Japanese multinationals. $R \& D$ Management, 31(1), 1-14.

Astley, G. W., Sachdeva, P. S. (1984). Structural Sources of Intraorganizational Power: A Theoretical Synthesis. Academy of Management Review, 9(1), 104-113.

Barney, J. (1991). Firm resources and sustained competitive advantage. Journal of Management, 17(1), 99-120.

Birkinshaw, J. M., \& Hood, N. (1998). Multinational subsidiary evolution: capability and charter change in foreign-owned subsidiary companies. Academy of Management Review, 23(4), 773-795.

Birkinshaw, J. M., Hood, N., \& Young, S. (2005). Subsidiary entrepreneurship, internal and external competitive forces, and subsidiary performance. International Business Review, 14(2), 227-248. 
Bonner, J. M., Orville, C., \& Walker, Jr. (2004). Selecting influential business-to-business customers in new product development: Relational embeddedness and knowledge heterogeneity considerations. Journal of Product Innovation Management, 21(3), 155-169.

Bouquet, C., \& Birkinshaw, J. (2008). Weight versus Voice: How Foreign Subsidiaries Gain Attention From Corporate Headquarters. Academy of Management Journal, 51(3), 577-601.

Brown, S. L., \& Eisenhardt, K. M. (1995). Product development: Past research, present findings, and future directions. Academy of Management Review, 20(2), 343-378.

Cantwell, J. (1994). The relationship between international trade and international production. In D. Greenway \& L. A. Winters (Eds.), Surveys in international trade. Oxford: Blackwell.

Cantwell, J., \& Janne, O. (1999). Technological globalisation and innovative centres: the role of corporate technological leadership a locational hierarchy. Research Policy, 28(2), 119-144.

Cantwell, J., \& Mudambi, R. (2005). MNE competence-creating subsidiary mandates. Strategic Management Journal, 26(12), 1109-1128.

Casciaro, T., \& Piskorski, M. J. (2005). Power imbalance, mutual dependence and constraint absorption: a closer look at Resource Dependence Theory. Administrative Science Quarterly, 50(2), 167-199.

Cassiman, B., \& Veugelers, R. (2006). In Search of Complementarity in the Innovation Strategy: Internal R\&D and External Knowledge Acquisition. Management Science, 52(1), 68-82.

Chang, S. J., van Witteloostuijn, A., \& Eden, L. (2010). From the Editors: Common method variance in international business research, Journal of International Business Studies, 41(2), 178-184.

Cho, H. J., \& Pucik, V. (2005). Relationship between innovativeness, quality, growth, profitability, and market value. Strategic Management Journal, 26(6), 555-575.

Ciabuschi, F., Dellestrand, H., \& Martín Martín, O. (2011). Internal Embeddedness, Headquarters Involvement, and Innovation Importance in Multinational Enterprises. Journal of Management Studies, 48(7), 1612-1639.

Ciabuschi, F., Forsgren, M., \& Martín Martín, O. (2012). Headquarters Involvement and Efficiency of Innovation Development and Transfer in Multinationals: A Matter of Sheer Ignorance? International Business Review, 21(2): 130-144. 
Cohen, J. (1988). Statistical power analysis for the behavioral sciences (2nd ed.). Hillsdale, N. J.: Erlbaum.

Cook, K. S., \& Emerson, R. M. (1978). Power, equity and commitment in exchange networks. American Sociological Review, 43(5), 721-739.

Dacin, M. T., Beal, D. C., \& Ventresca, M. J. (1999). The Embeddedness of Organizations: Dialogue \& Directions. Journal of Management, 25(3), 317-356.

Dyer, J., \& Hatch, N. W. (2006). Relation-specific capabilities and barriers to knowledge transfers: creating advantage through network relationships. Strategic Management Journal, 27(8), 710-719.

Dyer, J., \& Nobeoka, K. (2000). Creating and managing a high-performance knowledge-sharing network: the Toyota case. Strategic Management Journal, 21(3), 345-367.

Dyer, J. H., \& Singh, H. (1998). The Relational View: Cooperative Strategy and Sources of Interorganizational Competitive Advantage. Academy of Management Journal, 23(4), 660-679.

Echols, A., \& Tsai, W. (2005). Niche and Performance: The Moderating Role of Network Embeddedness. Strategic Management Journal, 26(3), 219-238.

Ettlie, J. E., Bridges, W. P., \& O'Keefe, R. (1984). Organization Strategy and Structural Differences for Radical versus Incremental Innovation. Management Science, 30(6), 682-695.

Fidler, L. A., \& Johnson, J. D. (1984). Communication and innovation implementation. Academy of Management Review, 9(4), 704-711.

Figueiredo, P. (2011). The role of dual embeddedness in the innovative performance of MNE subsidiaries: evidence from Brazil. Journal of Management Studies, 48(2), 417-440.

Figueiredo, P., \& Brito, K. (2011). The innovation performance of MNE subsidiaries and local embeddedness: evidence from an emerging economy. Journal of Evolutionary Economics, 21(1), $141-165$.

Fiol, C. M., \& Lyles, M. A. (1985). Organizational learning. Academy of Management Review, 10(4), 803-813.

Fjeldstad, O. D., \& Sasson, A. (2010). Membership matters: On the value of being embedded in customer networks. Journal of Management Studies, 47(6), 944-966.

Fornell, C. (1982). A second generation of multivariate analysis, Vol. 1: Methods. New York: Praeger. 
Fornell, C., \& Bookstein, F. L. (1982). Two structural equation models: LISREL and PLS applied to consumer exit-voice theory. Journal of Marketing Research, 19(November), 440-452.

Fornell, C., \& Larcker, D. (1981). Evaluating structural equation models with unobservable variables and measurement error. Journal of Marketing Research, 18(February), 39-50.

Forsgren, M., \& Holm, U. (2010). MNC headquarters' role in subsidiaries' value-creating activities: A problem of rationality or radical uncertainty. Scandinavian Journal of Management, 26(4), 421430.

Forsgren, M., Holm, U., \& Johanson, J. (2005). Managing the embedded multinational: A business network view. Cheltenham: Edward Elgar.

Foss, N. J. (1999). The Use of Knowledge in Firms. Journal of Institutional and Theoretical Economics, 155(3), 458-486.

Foss, N. J., \& Pedersen, T. (2002). Transferring knowledge in MNCs: the role of sources of subsidiary knowledge and organizational context. Journal of International Management, 8(1), 1-19.

Frenz, M., \& Ietto-Gillies, G. (2009). The impact on innovation performance of different sources of knowledge. Evidence from the UK Community Innovation Survey. Research Policy, 38(7), 1125 1135 .

Frost, T. (2001). The geographic sources of foreign subsidiaries' innovations. Strategic Management Journal, 22(2), 101-123.

Frost, T. S., Birkinshaw, J. M., \& Ensign, P. C. (2002). Centers of Excellence in Multinational Corporations. Strategic Management Journal, 23(11), 997-1018.

Gammelgaard, J., \& Pedersen, T. (2010). Internal versus external knowledge sourcing of subsidiaries and the impact of headquarters control. In U. Andersson \& U. Holm (Eds.), Managing the Contemporary Multinational: The Role of Headquarters. Cheltenham, U.K. and Northhampton, MA, U.S: Edward Elgar.

Garcia, R., \& Calantone, R. (2002). A critical look at technological innovation typology and innovativeness terminology: a literature review. Journal of Product Innovation Management, 19(2), 110-132. 
Garcia-Pont, C., Canales, J. I., \& Noboa, F. (2009). Subsidiary Strategy: The embeddedness Component. Journal of Management Studies, 46(2), 182-214.

Garud, R., Hardy, C. \& Maguire, S. (2007). Institutional entrepreneurship as embedded agency. An introduction to the Special Issue. Organization Studies, 28, 957-969.

Ghoshal, S., \& Bartlett, C. (1988). Creation, adoption, and diffusion of innovations by subsidiaries of multinational corporations. Journal of International Business Studies, 19(3), 365-388.

Ghoshal, S., \& Bartlett, C. A. (1990). The multinational corporation as an interorganizational network. Academy of Management Review, 15(4), 603-625.

Granovetter, M. (1985). Economic action and social structure: the problem of embeddedness. American Journal of Sociology, 91(3), 481-510.

Granovetter, M. (1992). Networks and organizations: Structure, form, and action. Boston, MA: Harvard Business School Press.

Gulati, R. (1998). Alliances and networks. Strategic Management Journal, 19(4), 293-317.

Hallin, C., Holm, U., \& Sharma, D. (2011). Embeddedness of innovation receivers in the multinational corporation: Effects on business performance, International Business Review, 20(3), 362-373.

Hansen, M. T. (1999). The search-transfer problem: the role of weak ties in sharing knowledge across organization subunits. Administrative Science Quarterly, 44(1), 82-111.

Helble, Y., \& Chong, L. C. (2004). The Importance of Internal and External R\&D Network Linkages for R\&D Organisations: Evidence from Singapore. $R \& D$ Management, 34(5), 605-612.

Heidenreich, M. (2012). The social embeddedness of multinational companies: a literature review. Socio-Economic Review, 10 (549-579)

Hertenstein, J. H., Platt, M. B., \& Veryzer, R. W. (2005). The Impact of Design Effectiveness on Corporate Financial Performance. Journal of Product Innovation Management, 22(1), 3-21.

Hillebrand, B., \& Biemans, W. G. (2004). Links between Internal and External Cooperation in Product Development: An Exploratory Study. Journal of Product Innovation Management, 21(1), 110 122.

Hitt, M. A., Hoskisson, R. E., Johnson, R. A., \& Moesel, D. D. (1996). The Market for Corporate Control and Firm Innovation. Academy of Management Journal, 39(5), 1084-1119. 
Holm, U., \& Pedersen, T. (2000). The Emergence and Impact of MNC Centres of Excellence: A Subsidiary Perspective. London: MacMillan.

Hulland, J. (1999). Use of partial least squares (PLS) in strategic management research: a review of four recent studies. Strategic Management Journal, 20(2), 195-204.

Kessler, E. H., Bierly, P. E., \& Gopalakrishnan, S. (2000). Internal vs. external learning in new product development: effects on speed, costs and competitive advantage. $R \& D$ Management, $30(3), 213-223$.

Kogut, B, \& Zander, U. (1993). Knowledge of the Firm and the Evolutionary Theory of the Multinational Corporation. Journal of International Business Studies, 24(4), 625-645.

Kostova, T., Roth, K. \& Dacin, M.T. (2008). Institutional theory in the study of multinational corporations: a critique and new directions, Academy of Management Review, 33, 994-1006.

Lane, P. J., \& Lubatkin, M. (1998). Relative Absorptive Capacity and Interorganizational Learning. Strategic Management Journal, 19(5), 461-477.

March, J. G., \& Sutton, R. I. (1997). Organizational Performance as a Dependent Variable. Organization Science, 8(6), 698-706.

Medcof, J. W. (2001). Resource-based Strategy and Managerial Power in Networks of Internationally Dispersed Technology Units. Strategic Management Journal, 22(11), 999-1012.

Meyer, K. E., Mudambi, R., \& Narula, R. (2011). Multinational Enterprises and Local Contexts: The Opportunities and Challenges of Multiple Embeddedness. Journal of Management Studies, 48(2), $235-252$.

Monteiro, L. F., Arvidsson, N., \& Birkinshaw, J. (2008). Knowledge flows within multinational corporations: Explaining subsidiary isolation and its performance implications. Organization Science, 19(1), 90-107.

Moran, P. (2005). Structural vs. relational embeddedness: social capital and managerial performance. Strategic Management Journal, 26(12), 1129-1151.

Mudambi, R., \& Navarra, P. (2004). Is knowledge power? Knowledge flows, subsidiary power and rent-seeking within MNCs'. Journal of International Business Studies, 35(5), 385-406. 
Nell, P. C., Ambos, B., \& Schlegelmilch, B. B. (2011). The MNC as an externally embedded organization: An investigation of embeddedness overlap in local subsidiary networks. Journal of World Business, 46(4), 497-505.

Ocasio, W. (2011). Attention to Attention. Organization Science, 22(5), 1-11.

Pearce, RD. (1999). Decentralised R\&D and strategic competitiveness: globalised approaches to generation and use of technology in multinational enterprises (MNEs). Research Policy, 28(2-3), $157-178$.

Peng, M. W., \& Luo, Y. (2000). Managerial Ties and Firm Performance in a Transition Economy: The Nature of a Micro-Macro Link. Academy of Management Journal, 43(3), 486-501.

Pfeffer, J., \& Salancik, G. R. (1978). The External Control of Organizations: A Resource Dependence Perspective. New York: Harper \& Row.

Pinch, S., Henry, N., Jenkins, M., \& Tallman, S. (2003). From industrial districts to knowledge clusters: A model of knowledge dissemination and competitive advantage in industrial agglomerations. Journal of Economic Geography, 3(4), 373-388.

Podolny, J. (2001). Networks as pipes and prisms of the market. American Journal of Sociology, 107(1), 33-60.

Podsakoff, P. M., MacKenzie, S. B., Lee, J. Y., \& Podsakoff, N. P. (2003). Common method biases in behavioral research: A critical review of the literature and recommended remedies, Journal of Applied Psychology, 88(5), 879-903.

Podsakoff, P. M., \& Organ, D. W. (1986). Self-Reports in Organizational Research: Problems and Prospects. Journal of Management, 12(4), 531-544.

Porter, M. E. (1983). The technological dimension of competitive strategy. In R. S. Rosembloom (Ed.), Researching on Technological Innovation, Management and Policy (pp. 11-33). Greenwich, CT: JAI Press.

Porter, M. E. (1990). The Competitive Advantage of Nations. New York: Free Press.

Porter, M. E., \& Fuller, M. (1986). Coalitions and global strategy. In M. Porter (Ed.), Competition in global industries (pp. 315-344). Boston: Harvard Business School. 
Porter, M. E., \& Sölvell, Ö. (1998). The Role of Geography in the Process of Innovation and the Sustainable Competitive Advantage of Firms. In A. D. Chandler, P. Hagstrom, \& O. Solvell (Eds.), The Dynamic Firm (pp. 440-457). London / New York: Routledge.

Prahalad, C. K., \& Doz, Y. L. (1981). An Approach to Strategic Control in MNCs. Sloan Management Review, 22(4), 5-13.

Prajogo, D. I. (2006). The Relationship between innovation and business performance - a comparative study between manufacturing and service firms. Knowledge and Process Management, 13(3), $218-225$.

Prajogo, D. I., \& Ahmed, P. K. (2007). The relationships between quality, innovation and business performance: an empirical study. International Journal of Business Performance Management, 9(4), 380-405.

Richard, P. J., Devinney, T. M., Yip, G. S., \& Johnson, G. (2009). Measuring Organizational Performance: Towards Methodological Best Practice, Journal of Management, 35(3), 718-804.

Richardson, G. B. (1972). The organization of industry. The Economic Journal, 82(327), 883-896.

Rowley, T., Behrens, D., \& Krackhardt, D. (2000). Redundant Governance Structures: An Analysis of Structural and Relational Embeddedness in the Steel and Semiconductor Industries. Strategic Management Journal, 21(3), 369-386.

Schmid, S., \& Schurig, A. (2003). The development of critical capabilities in foreign subsidiaries: disentangling the role of the subsidiary's business network. International Business Review, 12(6), $755-782$.

Schulz, M. (2003). Pathways of relevance: Exploring inflows of knowledge into subunits of multinational corporations. Organization Science, 14(4), 440-459.

Simonin, B. L. (1999). Ambiguity and the process of knowledge transfer in strategic alliances. Strategic Management Journal, 20(7), 595-623.

Simsek, Z., Lubatkin, M., \& Floyd, S. W. (2003). Inter-firm networks and entrepreneurial behavior: A structural embeddedness perspective. Journal of Management, 29(3), 427-442.

Stieglitz, N., \& Heine, K. (2007). Innovations and the role of complementarities in a strategic theory of the firm. Strategic Management Journal, 28(1), 1-15. 
Stone, M. (1974). Cross-validatory Choice and Assessment of Statistical Predictions. Journal of the Royal Statistical Society. Series B, 36(2), 111-147.

Szulanski, G., \& Jensen, R. J. (2006). Presumptive adaptation and the effectiveness of knowledge transfer. Strategic Management Journal, 27(10), 937-957.

Takeishi, A. (2001). Bridging inter- and intra-firm boundaries: Management supplier involvement in automobile product development. Strategic Management Journal, 22(5), 403-433.

Teece, D. J. (1977). Technology Transfer by Multinational Firms: The Resource Cost of Transferring Technological Know-How. Economic Journal, 87(346), 242-261.

Tidd, J. (1995). Development of novel products through intraorganizational and interorganizational networks: the case of home automation. Journal of product innovation management, 12(4), 307322.

Tracey, M., Lim, J., \& Vonderembse, M. A. (2005). The impact of supply-chain management capabilities on business performance. Supply Chain Management, 10(3), 179-191.

Tsai, W. (2001). Knowledge transfer in intra-organizational networks: Effects of network position and absorptive capacity on business unit innovation and performance. Academy of Management Journal, 44(5), 996-1004.

Uzzi, B. (1996). The Sources and Consequences of Embeddedness for Economic Performance of Organizations: The Network Effect. American Sociological Review, 61(4), 674-698.

Uzzi, B. (1997). Social structure and competition in interfirm networks. The paradox of embeddedness. Administrative Science Quarterly, 42(1), 35-67.

Von Hippel, E. (1988). Sources of Innovation. Oxford: Oxford University Press.

Von Hippel, E. (1994). Sticky information and the locus of problem solving: Implications for innovation. Management Science, 40(4), 429-439.

Werts, C., Linn, R., \& Joreskog, K. (1974). Intraclass reliability estimates: Testing structural assumptions. Educational and Psychological Measurement, 34(1), 25-33.

Wold, H. (1982). Soft Modeling. The Basic Design and Some Extensions. In K. G. Jöreskog, \& H. Wold (Eds.), Systems Under Indirect Observation. Amsterdam: North Holland. 
Yamin, S., Mavondo, F., Gunasekaran, A., \& Sarros, J. (1997). A study of competitive strategy, organizational innovation and organizational performance among Australian manufacturing companies. International Journal of Production Economics, 52(1), 161-172.

Zander, U. (1991). Exploiting a technological edge: Voluntary and involuntary dissemination of technology. Stockholm: Institute of International Business, Stockholm School of Economics.

Zukin, S., \& DiMaggio, P., (1990). Structures of capital: The social organization of the economy. Cambridge, MA: Cambridge University Press. 
Figure 1

The hypothesized model

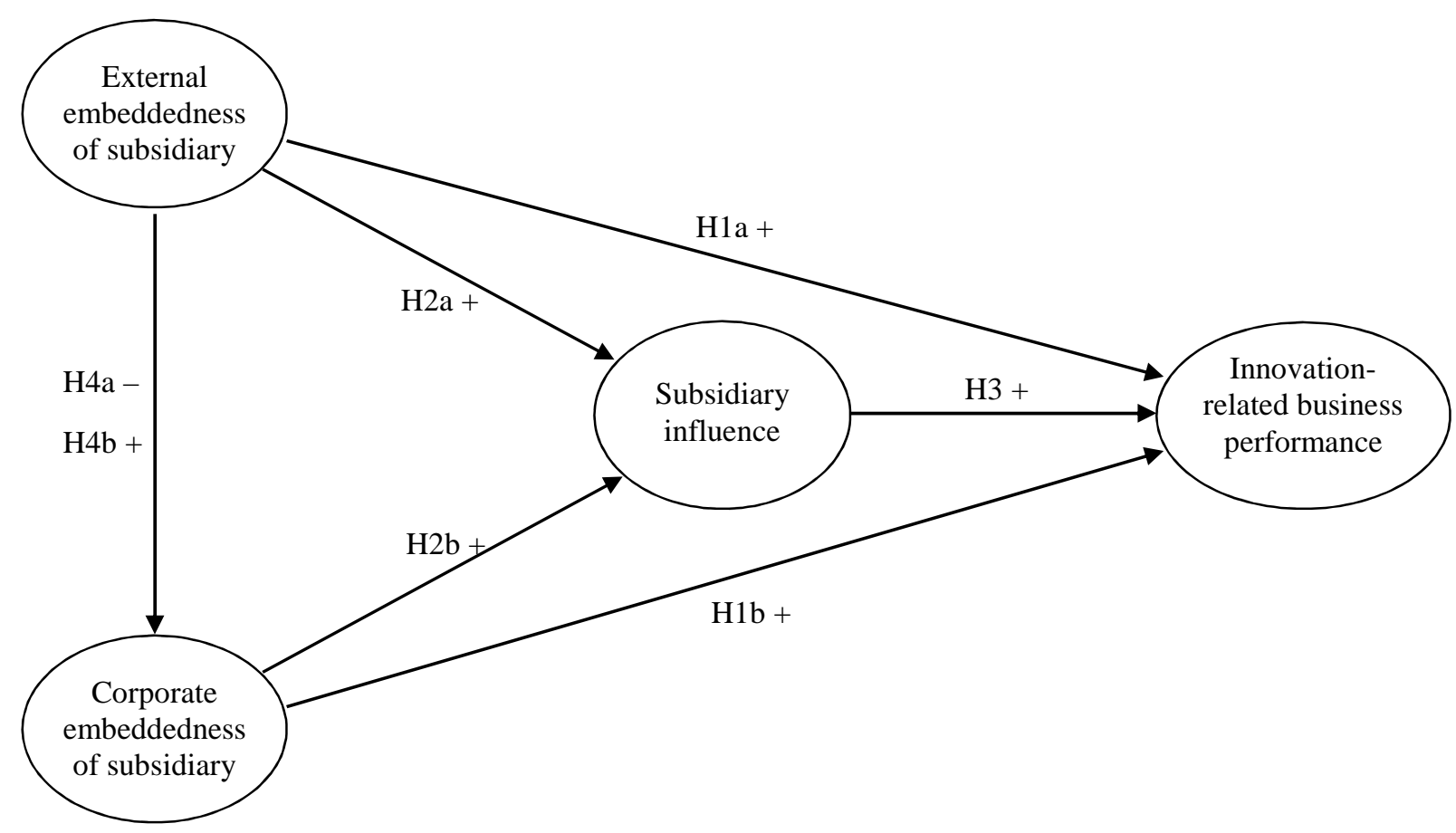


Figure 2

The resulting model

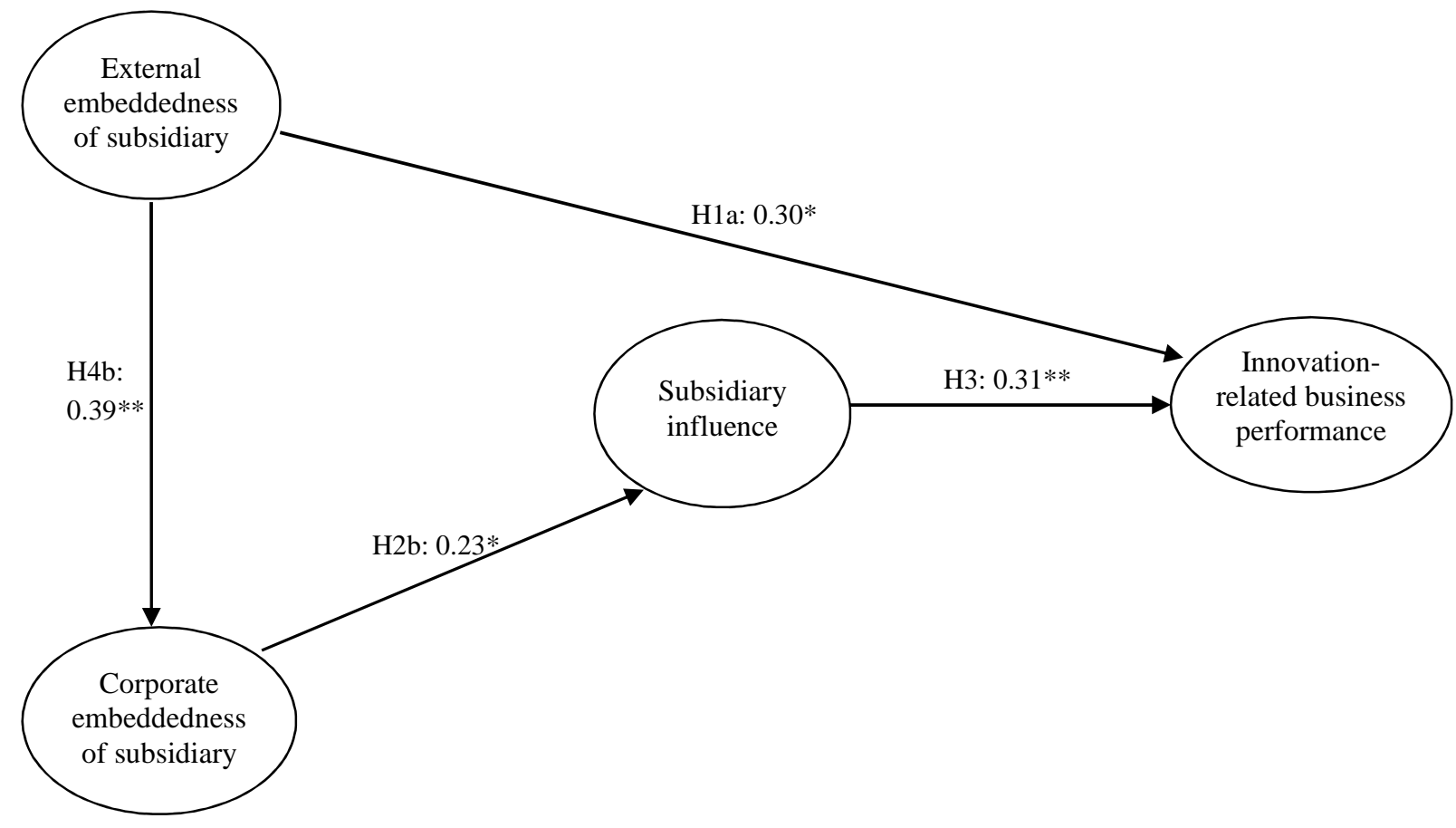

$* \mathrm{p}<0.05 ; * * \mathrm{p}<0.01$ (based on a Student $\mathrm{t}_{(499)}$ distribution with one tail). 
Table 1

Item and construct reliability and average variance extracted

\begin{tabular}{lccc}
\hline & Item reliability & $\begin{array}{c}\text { Construct } \\
\text { reliability } \\
\text { Composite } \\
\text { reliability }\end{array}$ & $\begin{array}{c}\text { Convergent } \\
\text { validity } \\
\text { Average Variance } \\
\text { Extracted (AVE) }\end{array}$ \\
\hline Business performance & Loading & 0.79 & 0.57 \\
Perf1 & 0.80 & & \\
Perf2 & 0.83 & & \\
Perf3 & 0.62 & 0.81 & 0.59 \\
Subsidiary influence & & & \\
Influen1 & 0.69 & & \\
Influen2 & 0.75 & 0.77 & \\
Influen3 & 0.85 & & \\
Corporate embeddedness & & & \\
CEmbed1 & 0.72 & & \\
CEmbed2 & 0.75 & 0.53 & \\
CEmbed2 & 0.71 & \\
External embeddedness & & & \\
EEmbed1 & 0.75 & & \\
EEmbed2 & 0.74 & \\
EEmbed3 & 0.73 & \\
\hline
\end{tabular}


Table 2

Endogenous variables: Direct and total effects, explained variances and Stone-Geisser $\mathrm{Q}^{2}$ test

\begin{tabular}{lccccc}
\hline Effects on endogenous variables & Direct effect & $\begin{array}{r}\text { t value } \\
\text { (bootstrap) }\end{array}$ & $\begin{array}{r}\text { Total } \\
\text { effects }\end{array}$ & $\begin{array}{r}\text { Variance } \\
\text { explained }\end{array}$ & $\begin{array}{c}\text { Stone- } \\
\text { Geisser } \mathbf{Q}^{2}\end{array}$ \\
\hline Effects on business performance & & & & 0.243 & -0.03 \\
H1a: External embeddedness & $0.30 *$ & $(1.86)$ & 0.30 & 0.068 & \\
H3: Subsidiary influence & $0.31 * *$ & $(2.74)$ & 0.31 & 0.101 & \\
Type of innovation (process) & $-0.30 * *$ & $(2.79)$ & -0.30 & 0.074 & \\
Effects on subsidiary influence & & & & 0.222 & -0.03 \\
H2b: Corporate embeddedness & $0.23 *$ & $(1.71)$ & 0.23 & 0.062 & \\
Development cost & $0.39 * * *$ & $(3.34)$ & 0.39 & 0.160 & \\
Effects on corporate embeddedness & & & & 0.153 & -0.20 \\
H4b: External embeddedness & $0.39 * *$ & $(2.61)$ & 0.39 & 0.153 & \\
\hline
\end{tabular}

$* \mathrm{p}<0.05 ; * * \mathrm{p}<0.01 ; * * * \mathrm{p}<0.001$ (based on a Student $\mathrm{t}_{(499)}$ distribution with one tail) 


\section{Appendix A}

Operationalization of the constructs and descriptive statistics

\begin{tabular}{|c|c|c|c|c|}
\hline Construct/ Indicator & Mean & SD & Scale & Label \\
\hline Business performance & & & & Perf \\
\hline \multicolumn{5}{|l|}{ Evaluate how the innovation has affected your own unit: } \\
\hline The innovation has affected your unit business volume in your home country & 1.44 & 1.07 & -3 to 3 & Perf1 \\
\hline \multicolumn{5}{|l|}{ Market } \\
\hline The innovation has affected your unit competitive advantage on the market & 2.12 & 0.79 & -3 to 3 & Perf2 \\
\hline The innovation has affected your unit operating profit & 1.38 & 1.23 & -3 to 3 & Perf3 \\
\hline Subsidiary influence & & & & Influen \\
\hline \multicolumn{5}{|l|}{ Evaluate how the innovation has affected your own unit: } \\
\hline The innovation has affected your unit advantage within the MNC & 1.55 & 1.05 & -3 to 3 & Influen1 \\
\hline $\begin{array}{l}\text { The innovation has affected your own unit influence on decisions about } \\
\text { investments in your production capability }\end{array}$ & 0.90 & 1.09 & -3 to 3 & Influen2 \\
\hline $\begin{array}{l}\text { The innovation has affected your own unit influence on decisions about } \\
\text { investments in your R\&D }\end{array}$ & 1.16 & 1.09 & -3 to 3 & Influen3 \\
\hline $\begin{array}{l}\text { Corporate embeddedness (relationships within the MNC that have } \\
\text { been important for the innovation) }\end{array}$ & & & & CEmbed \\
\hline \multicolumn{5}{|l|}{$\begin{array}{l}\text { With regard to the corporate counterpart and innovation development, evaluate } \\
\text { the following statements: }\end{array}$} \\
\hline HQ has fully supported your interest in developing this innovation & 5.25 & 1.74 & 1 to 7 & CEmbed 1 \\
\hline The cooperation with HQ has been characterized by frequent interaction & 3.01 & 2.05 & 1 to 7 & CEmbed 2 \\
\hline This counterpart has been important for your business for a very long time & 5.29 & 1.64 & 1 to 7 & CEmbed 3 \\
\hline External embeddedness (relationships external to the MNC that & & & & EEmbed \\
\hline \multicolumn{5}{|l|}{ have been important for the innovation) } \\
\hline \multicolumn{5}{|l|}{ With regard to the external counterpart, evaluate the following statements: } \\
\hline $\begin{array}{l}\text { You have a close business relationship in terms of sales and purchase of } \\
\text { goods and services }\end{array}$ & 3.77 & 2.45 & 1 to 7 & EEmbed 1 \\
\hline $\begin{array}{l}\text { You have adapted your resources and activities very much to this } \\
\text { counterpart }\end{array}$ & 3.07 & 1.83 & 1 to 7 & EEmbed2 \\
\hline This counterpart has been important for your business for a very long time & 3.88 & 2.06 & 1 to 7 & EEmbed3 \\
\hline Firm size (number of employees) & 740.10 & 1078.04 & Ratio & FSize \\
\hline Development cost & & & & DCost \\
\hline $\begin{array}{l}\text { To develop the innovation technology/process know-how, you had to } \\
\text { invest significantly in specialized equipment and facilities }\end{array}$ & 3.70 & 2.29 & 1 to 7 & DCost 1 \\
\hline $\begin{array}{l}\text { To develop the innovation technology/process know-how, you had to } \\
\text { invest significantly in skilled human resources }\end{array}$ & 3.65 & 2.34 & 1 to 7 & DCost2 \\
\hline Time since the innovation was released & 5.39 & 4.34 & Ratio & Time \\
\hline
\end{tabular}




\section{Appendix B}

Discriminant validity: Correlations and square root of the average variances extracted (AVE $\left.{ }^{a}\right)$

\begin{tabular}{lcccccr}
\hline Construct & Perf & Influen & CEmbed & EEmbed & DCost & Type $^{\mathrm{b}}$ \\
\hline Perf & $\mathbf{0 . 7 5}$ & & & & & \\
Influen & 0.32 & $\mathbf{0 . 7 7}$ & & & & \\
CEmbed & 0.21 & 0.27 & $\mathbf{0 . 7 3}$ & & & \\
EEmbed & 0.22 & -0.03 & 0.39 & $\mathbf{0 . 7 4}$ & & \\
DCost & 0.15 & 0.41 & 0.11 & 0.02 & $\mathbf{0 . 8 6}$ & \\
Type $^{\mathrm{b}}$ & -0.25 & -0.07 & 0.17 & 0.25 & 0.16 & $\mathbf{1}$
\end{tabular}

a: Diagonal values in bold are the square root of the variance shared between the reflective constructs and their measures. In order to achieve discriminant validity, the diagonal elements (square roots of AVE) must be larger than the off-diagonal ones (correlations).

b: Type of innovation (process) 